\title{
Education Basics Of Financial Planning Prospective Intern Japan
}

\author{
Aji Erlangga, Novfitri Landong Namora Sihombing, Amrizal, Henny Mulyati \\ Institute of Technology and Business Ahmad Dahlan Jakarta
}

novfitri.lns@gmail.com

Submitted: February $19^{\text {th }}, 2020 \quad$ Revised: March $12^{\text {th }}, 2020 \quad$ Published: March $30^{\text {th }} 2020$

\begin{abstract}
Japanese technical apprenticeship opportunities for developing countries, including Indonesia. The program is called with the Technical Internship Training Program officially run by the respective governments. Apprentices from Indonesia had the opportunity to undergo an internship program for three years and earn wages while in Japan. Delivery interns from Indonesia, operationally performed by LPK (Employment Training Institute), who get permits and supervised by the Ministry of Manpower. Preparations made by the CAB include language training and technical skills, but not include things beyond the core financial management program. With the chance to get a monthly income that is worth 3-4 times more than the minimum wage in Indonesia, but only lasted three years (36 months), then the knowledge of the purpose and financial planning becomes essential. Activities by the Indian Institute of Technology and Business Ahmad Dahlan fill the void giver material in the aspect of financial literacy.
\end{abstract}

Keywords: Education, Financial Literacy, Financial Planning, Intern Japan

\section{INTRODUCTION}

Indonesia. FSA (2017) defines financial literacy as the knowledge, skills, and beliefs that influence attitudes and behavior to improve the quality of decision-making and business management to achieve prosperity. The person is said to well literate if they have the knowledge and confidence of the institutions, products, and financial services, as well as skills in knowing the features, benefits, risks, rights, and obligations of financial products and services mentioned. Financial literacy becomes essential where the public can determine what financial products and services that fit their needs to improve their quality of life sustainably(Febrianty \& Divianto, 2020).

Under the FSA survey in 2016, the national financial literacy index amounted to $29.66 \%$. Up slightly from a study in 2013 , that is equal to $21.84 \%$. Show that the majority of people have not classified to understand (literate) in financial affairs. On the whole, the FSA describes the benefits of the concept of financial literacy will bring results in the form of economic well-being, as in the following figure:

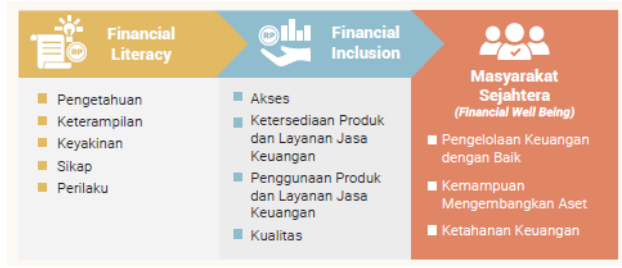




\section{Image 1. Financial Literacy Concept}

Institute of Technology and Business Ahmad Dahlan (ITB-AD), as one of the private universities in Muhammadiyah, has a target in the form of an increase in the number of community service (frequency and goals) in Higher Education Strategic Plan 2016 -2021. Community service efficiently carried out if it can optimize the competencies possessed by the majority of faculty educational background in Management and Accounting. Analysis of community service programs are among others in line and support the national issue is financial literacy(Rulandari \& Sudrajat, 2017; Sofyan, 2019).

As pioneered by the FSA since 2013 (revisit 2017), the ITB-AD participates in the National Strategy for Financial Literacy Indonesia. Following the method of the FSA's approach, the approach of the activities carried out by three types of procedures:

1. Geographical approach (based on location).

2. We are approaching the target (by the community).

3. We are approaching the sectoral (by sector or type of financial institution).

Community service activities by ITB-AD using a targeted approach is the approach to community groups (profession) prospective interns to Japan that began in the first quarter of 2019.

The reasons for selecting the method of approach through targeted approaches (community) done for several reasons:

1. Analysis of the opportunities which found that international cooperation and access to higher education can be carried out by the college, either through having direct or through Indonesian parties, have activities with outside parties.

2. Analysis that Japan is one of Indonesia's strategic partners in the social, economic, and business. Besides, Indonesia-Japan relations over the last 30 years do not cause problems or socio-political resistance from the public. It can say that the relationship between Indonesia and Japan have taken place after the Japanese occupation ended in 1945, where an intense relationship Indonesia Japan woke up during the New Order in the 1970s marked by the construction of the Japanese industry in Indonesia.

3. Official Japanese government program for developing countries to participate in a program called Technical Internship Training Program (TIPT) since 1993. The program aims to transfer skills, technology, and knowledge gained in Japan to build other countries. The program also aims to improve international cooperation through the development of human resources, which play a crucial role in the economic sector in developing countries.

4. TIPT activities carried out in the form of internships (internship) to the corporate in Japan for three years. The program is supervised and regulated by government agencies that JITCO (Japan International Cooperation Agency) for developing countries. Types of jobs offered some 80 posts covering various areas of work include construction, manufacturing, services (hospitality), flight, nurse, and agriculture. Apprentices are restricted aged 19 to 30 years.

5. The number of apprentices per December 31, 2018, amounted to 328360 people (2019, JITCO) with countries of origin apprentices are: from Vietnam (50.1\%), China (23.7\%), the Philippines (9.2\%), Indonesia ( $8.2 \%)$, Thailand (2.9\%) and other countries $(5.8 \%)$.

6. The Indonesian government, case the Ministry of the Labor Republic Indonesia, is consistently continuing the program that has been initiated by the Ministry of Labor as a 
partner with JITCO. Since 1993 Indonesia has participated in sending trainees at Japanese companies. This activity involves the government and private sectors of Indonesia as an institution that conducts delivery (sending organization) trainees to Japan.

The delivery scheme the following figure:

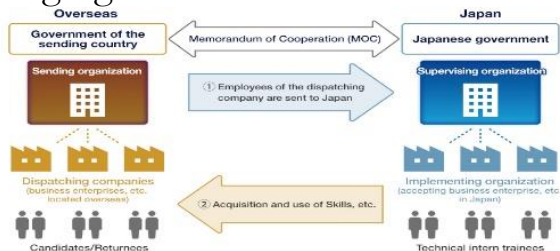

Image 2.Delivery Apprenticeship Scheme

Implementation of the program and followed TIPT desirable because it provides economic benefits for Japanese companies and apprentices. Based on the interests of the business operation because of the availability of internships, in return, companies where apprentices provide apprenticeship wage. Apprentice wage is worth more than the average salary received formal workers in the countries of origin. For example, the highest minimum wage in Indonesia is UMR Karawang district of Rp4.234.010 (2019), while the wages of apprentices in Japan worth JPY 100,000 (worth Rp13 million at the rate of JPY $1=f, 130$ ). There are two critical events in Japan, which then affects TIPT by the Japanese in recent years:

1. The decline in the number of residents (shrinking population) Japan since 2010. It is the effect of the decrease in birth rate effect of decreasing the number of children, which causes a decline in population. The composition of population decline in the numbers of children (under 15 years) continued to occur from 1982 until now (2018, Statistics Bureau of Japan). Currently, the population of Japan was 126.25 million (2019, the Statistics Bureau of Japan).

2. A decline in population is mainly a decrease in the working-age population, causing Japan to experience labor shortages at the level of labor (labor) in the various sectors. Led the Japanese government to revise the rules of the Immigration Control and Refugee Recognition Act of 1 April 2019. This rule allows for unskilled workers or semi-skilled as a "trainee" through an apprenticeship program, which was initially three years to 5 years in Japan. With the rule change, then Japan will receive up to an additional 345 thousand of workers.

Japanese conditions were experiencing labor shortages in contrast to Indonesia. Some facts related to the labor force and unemployment in Indonesia are as follows:

1. Number of the Indonesian labor force in February 2019 some 136 million people, which means an increase of 2 million compared to data collected in February 2018 (in 2019, BPS).

2. The unemployment rate amounted to $5.01 \%$ or numbered about 6,8 juta soul.

3. Based on the education of unemployed, the majority are high school graduates, and the vocational school, the most top unemployment composition, is respectively $6.7 \%$ and $8.6 \%$.

4. Furthermore, when we further look at the composition of their work, the structure of formal workers totaled 55.28 million $(42.73 \%$ ), and non-formal workers totaled 74.08 million $(57.27 \%)$.

5. Suppose we once again look further, then the average wage/salary of laborers/employees/employee is Rp3,05 million per month in February 2019 (in 2019, BPS). 
There suggests that low-income workers and the unemployed in the age of the workforce be a problem in Indonesia. These events are open to encourage the demand and supply of interns from Indonesia.

Departures trainee in Indonesia is done by the private sector, which has an operating license for the delivery of the Government of Indonesia (Kemenaker RI) and has the recipient agency partners in Japan. The recipient institution partners associated with the company receiving an internship in Japan. Recipient institutions in Japan have officially registered agencies in the Japanese government (JITCO). Shape sending institutions in Indonesia under regulation Kemenaker RI is LPK (job training institutions).

Preparations made by the $\mathrm{CAB}$ in Indonesia is:

1. Training of prospective interns to Japan.

2. We are providing better facilities for selection by the recipient company intern Japanese conducted in Indonesia.

3. We are handling eligibility compliance departure, namely health and fulfillment of documents (work permit and visa).

4. Japanese language training.

5. Training and technical skill of internships, e.g., construction skill, food made skill, welding skill, etc.

Based on visits and gathering information, known that there are problems outside core activities, namely:

1. The first problem is a reasonably high debt as part of preparations before leaving for Japan. These funding needs arise in the form of language training costs, the cost of health checks, living expenses (accommodation, food, transport), and the processing of documents (passports, visas, work permits).

2. The second problem is the low level of financial literacy in the form of ignorance of financial products and services, as well as not understanding objectives and financial planning. It can lead to the creation of financial wellness in the medium term (return from Japan) and a long time (go back to work and live in Indonesia).

The second issue of proficiency level, ITB-AD, held a training program for the second problem. This knowledge his given as preparation before departing internship in Japan and after returning from Japan, so that they understand financial management in a simple

\section{METHOD}

The methods used during training are lectures, discussions, and exercises with the following caption:

1. Explanation using PowerPoint material contains the concept (narration), photographs, and illustrations that include financial planning.

2. Participants have given a paper exercise that has been printed and charged at the time of training in the form of a form of financial objectives, financial planning, and simulation calculations.

For post-training (post-training), paper drills are also provided in softcopy for participants to repeat or recalculate the planning and allocation of funds held while on the internship program in Japan. Steps taken are as follows:

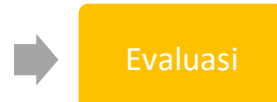


Education Basics of Financial Planning Prospective Intern Japan

Airlangga, Sihombing, Amrizal, Mulyati

\section{Image.3. Program Implementation Stages}

\section{Preparation phase}

Election Community Group

Targetting, namely the determination of prospective interns who will educate. The target setting based on the criteria that the sending institution (LPK) to cooperate, regularly sends interns to Japan and has many participants at least ten people per class.

preparation of matter

1. The material has designed consists of several parts:

a. A general overview of the number of admissions during an internship in Japan;

b.Concepts and examples of goals and financial planning;

c. Exercise planning and use of funds for Japan;

2. This material should be kept simple and easy to understand.

\section{Implementation phase}

Implementation has done with visits and training. The training has done on days when interns are currently not receiving core training is language training and skills.

\section{Evaluation phase}

This phase has done in 2 ways:

1. Meeting with the $\mathrm{CAB}$ about the effectiveness of the material submitted by the lecturer of ITB-AD;

2. Internal meeting fellow actors led by the chairman of the community service Project Team, as well as by the Rector or the Vice-Rector;

\section{RESULT AND DISCUSSION}

The selection of these targets was conducted in January and February 2019 through information and introductions to members of the Association of Shipping Apprenticeship of Foreign Affairs of Japan (AP2LN). LPK recommendation and readiness in accepting community service activities are the two institutions that Risen LPK LPK Indonesia in Jakarta and Bandung Mulia Mandiri. This activity has been going on:

Table.1. Training activities

\begin{tabular}{|c|c|c|c|}
\hline date & locations & $\begin{array}{c}\text { Lecturers } \\
\text { involved }\end{array}$ & $\begin{array}{l}\text { Number of } \\
\text { participants }\end{array}$ \\
\hline $\begin{array}{l}\text { January } 25, \\
2019\end{array}$ & $\begin{array}{l}\text { LPK } \\
\text { Mulia } \\
\text { Mandiri }\end{array}$ & 1 & 31 people \\
\hline $\begin{array}{l}\text { February 23, } \\
2019\end{array}$ & $\begin{array}{l}\text { LPK } \\
\text { Revive } \\
\text { Indonesia }\end{array}$ & 1 & 18 people \\
\hline March 1st, 2019 & $\begin{array}{l}\text { LPK } \\
\text { Mulia } \\
\text { Mandiri }\end{array}$ & 2 & 32 people \\
\hline March 31, 2019 & $\begin{array}{l}\text { LPK } \\
\text { Revive } \\
\text { Indonesia }\end{array}$ & 2 & 45 people \\
\hline $\begin{array}{l}\text { August 10th, } \\
2019\end{array}$ & $\begin{array}{l}\text { LPK } \\
\text { Revive } \\
\text { Indonesia }\end{array}$ & 2 & 60 people \\
\hline
\end{tabular}


At the start of the material, Candidates as given an explanation apprentice working atmosphere in Japan and some form of work they do there.

The first material: Prospective interns have explained what it needs and wants. And they were asked to write down ten their needs and desires when they have money (salary) after an internship in Japan for three years as the table below:

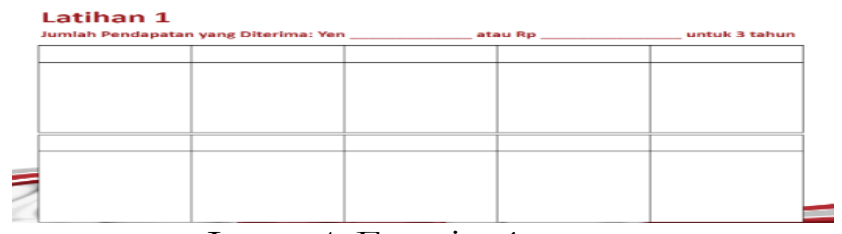

Image 4. Exercise 1.

The second material: This material has focused on financial planning, prospective interns explained why humans need to carry out economic activities, three things underlie human conduct economic activities, namely:

1. Meet the needs alone

2. welfare of the family

3. Designing the future

Then prospective interns are given an explanation understanding of financial planning in general, and the steps in financial planning, as well as the financial condition of future inflation, will come. Given this, intern candidates need to know there are four reasons for financial planning is crucial for prospective interns are:

1. Ensuring financial goals following the purpose of life

2. Meet the necessities of life that are sustainable

3. Realizing dreams in life

4. Happy and unhappy

Application of the above, prospective interns to practice the exercises into two, namely Financial goals $=$ The goal of life as the table below:

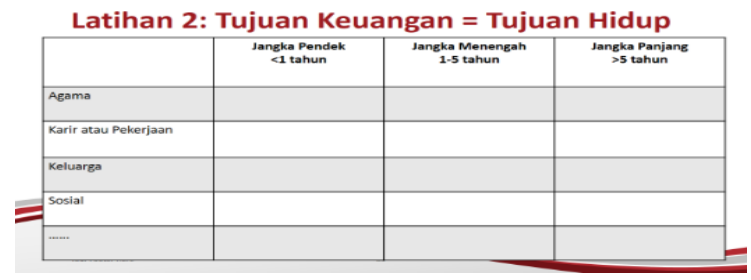

Image.5. exercise 2

After practicing drills to 2, furthermore, prospective interns are explained sustainable basic needs like-the table below:

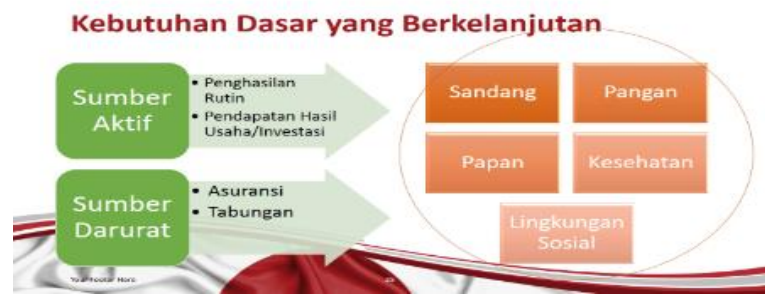

Image.6.Needs a sustainable basis 
Education Basics of Financial Planning Prospective Intern Japan

Airlangga, Sihombing, Amrizal, Mulyati

The theory practiced with a potential intern. I.e. exercises to 3, in which the intern candidates asked to write three big dreams in life.

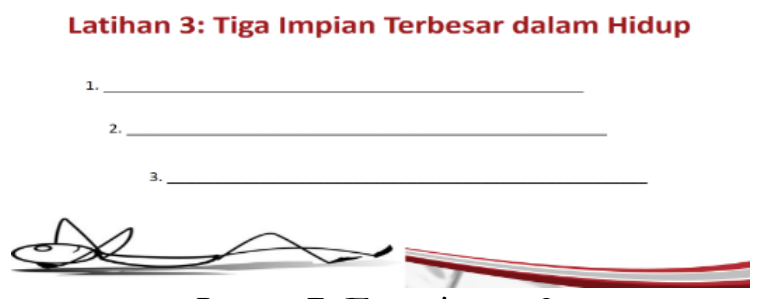

Image 7. Exercise to 3

Not quite there, the next activities are those exercises to 4 on happy. In this case, they have written to who and How can the way they are so glad themselves and the people they care about and love. The following is

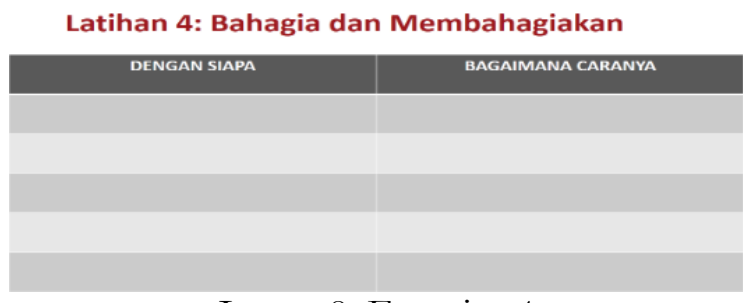

Image 8: Exercise 4

After training to 4, prospective interns in Japan given examples of the financial activities of interest as below

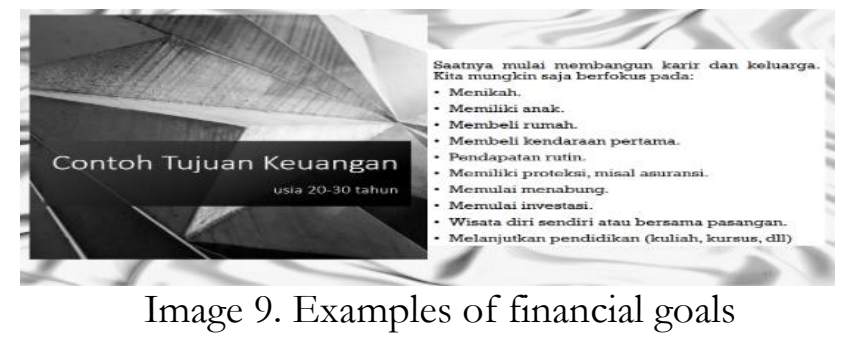

The not only example of the general financial goals, but prospective interns we also gave financial goals examples 41-50 years of age. This show the figure below:

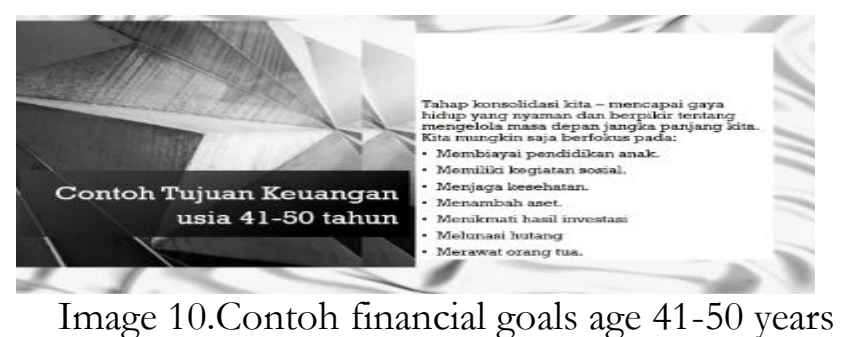

material cover • Information about the spending priorities, as shown below: 


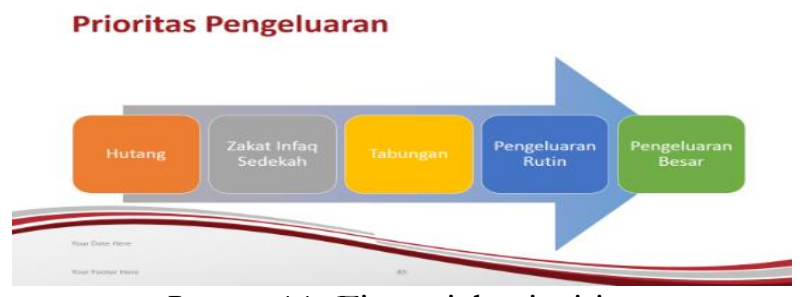

Image 11. Financial priorities

Prospective interns are reminding that priorities financial expenses they can plan and manage spending with neat, give for them after comeback from Japan they no longer have difficulties in finance, trouble meeting their needs, challenges welfare of his family and the extreme challenge of designing the future front after return from Japan. To better understand the above, they asked to do a dress rehearsal as the following example:

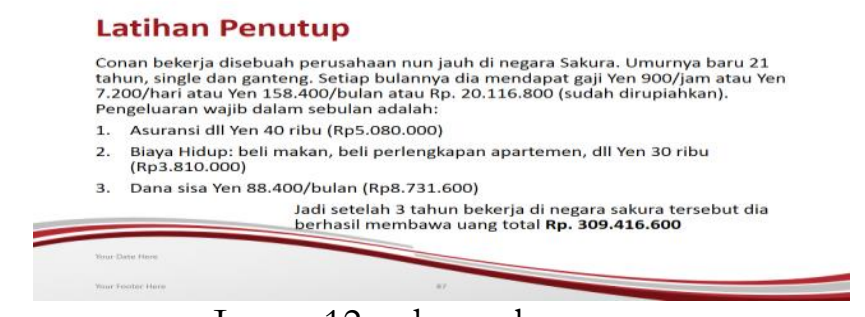

Image 12. rehearsal

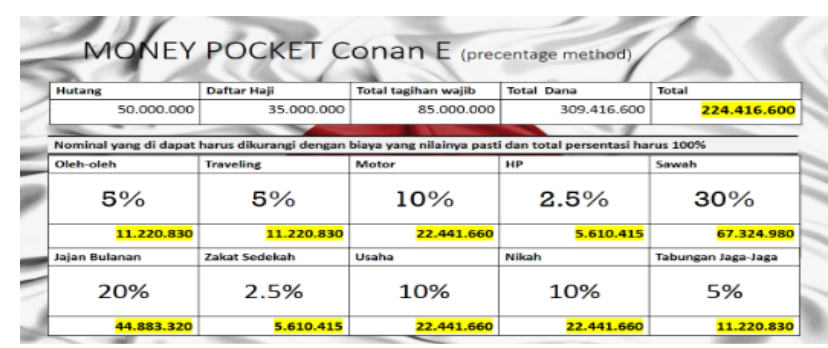

Image 13: Money Pocket Conan

From the above example, further prospective intern practice drills to 5 (Cart), as shown below:

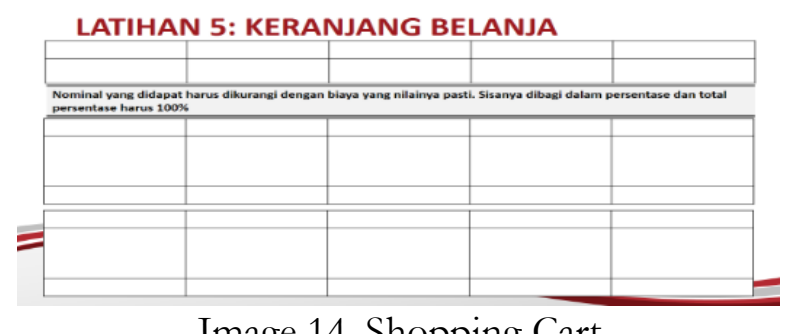

Image 14. Shopping Cart

The exercise above can give a clear picture for potential interns when they returned from Japan on planning, financial processing, systematic and straightforward. So that they can use the results of their labor for three years can be used properly. 
Education Basics of Financial Planning Prospective Intern Japan

Airlangga, Sihombing, Amrizal, Mulyati
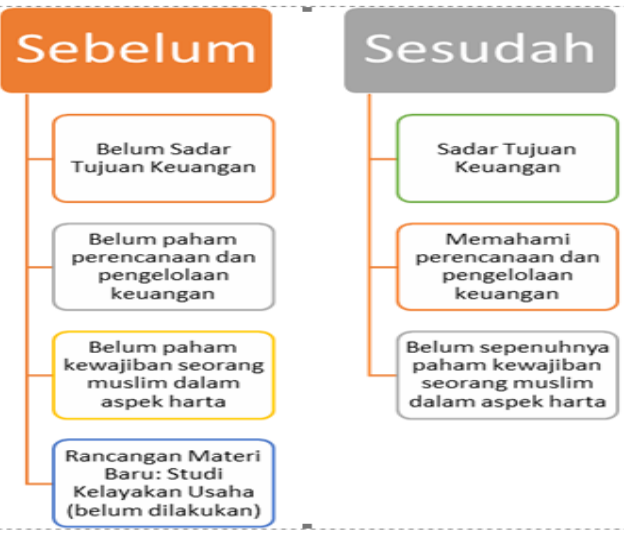

Image 15.Chart Evaluation

Evaluation of material carried on the analysis of the impact:

1. Content that is awareness has been successful.

2. The real understanding of financial planning and management has been successful.

3. Material about Muslims in their obligation treasure aspects needs to improve by including a professor of Al Islam and Kemuhammadiyahan.

4. The new material will be compiled, i.e., feasibility studies.

Party Mulia Mandiri and LPK LPK Revive Indonesia have asked the ITB-AD to be able to run this program regularly every two months (LPK Mulia Mandiri), and every month LPK Revive Indonesia.

\section{Activities photos}
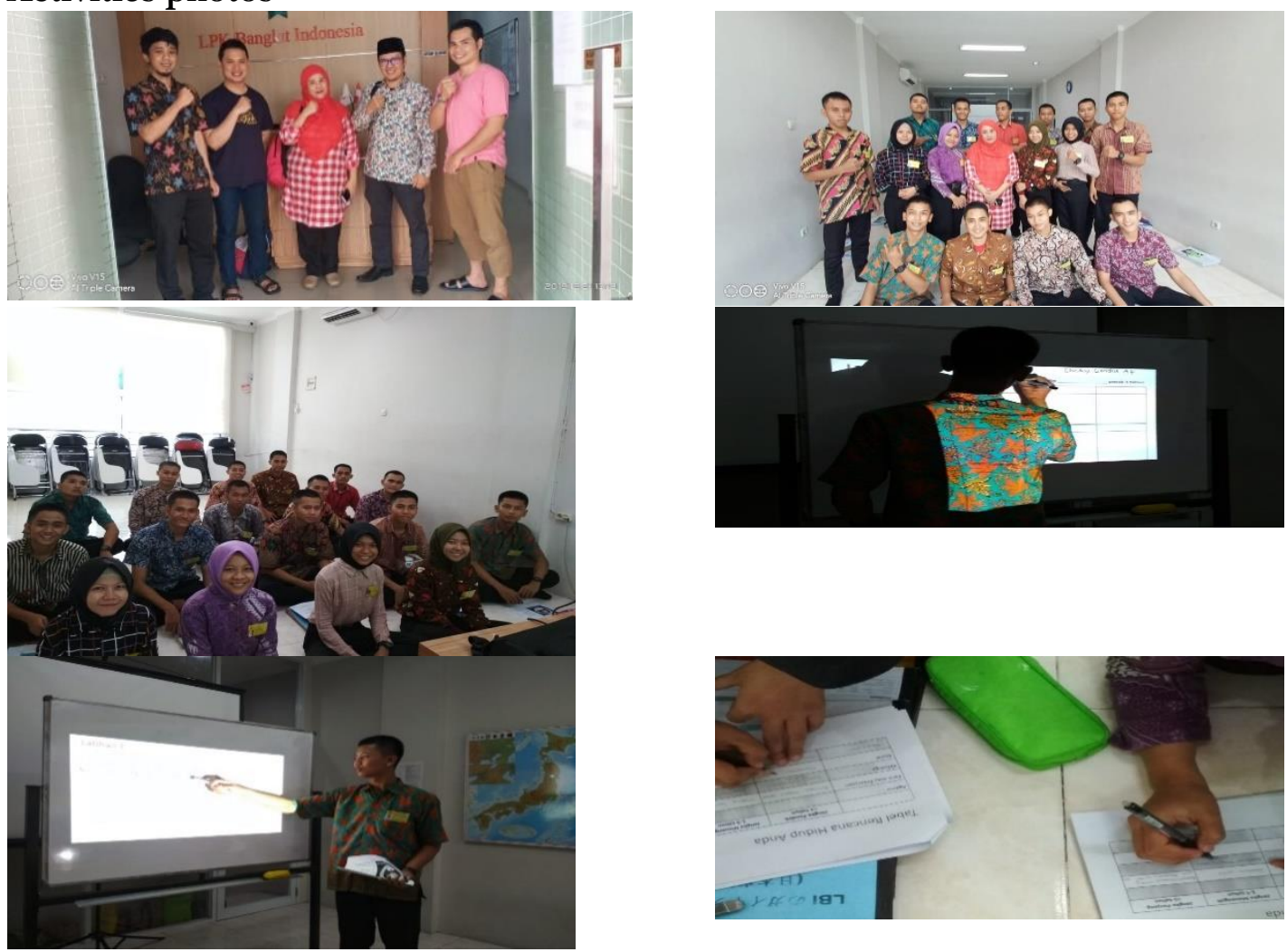

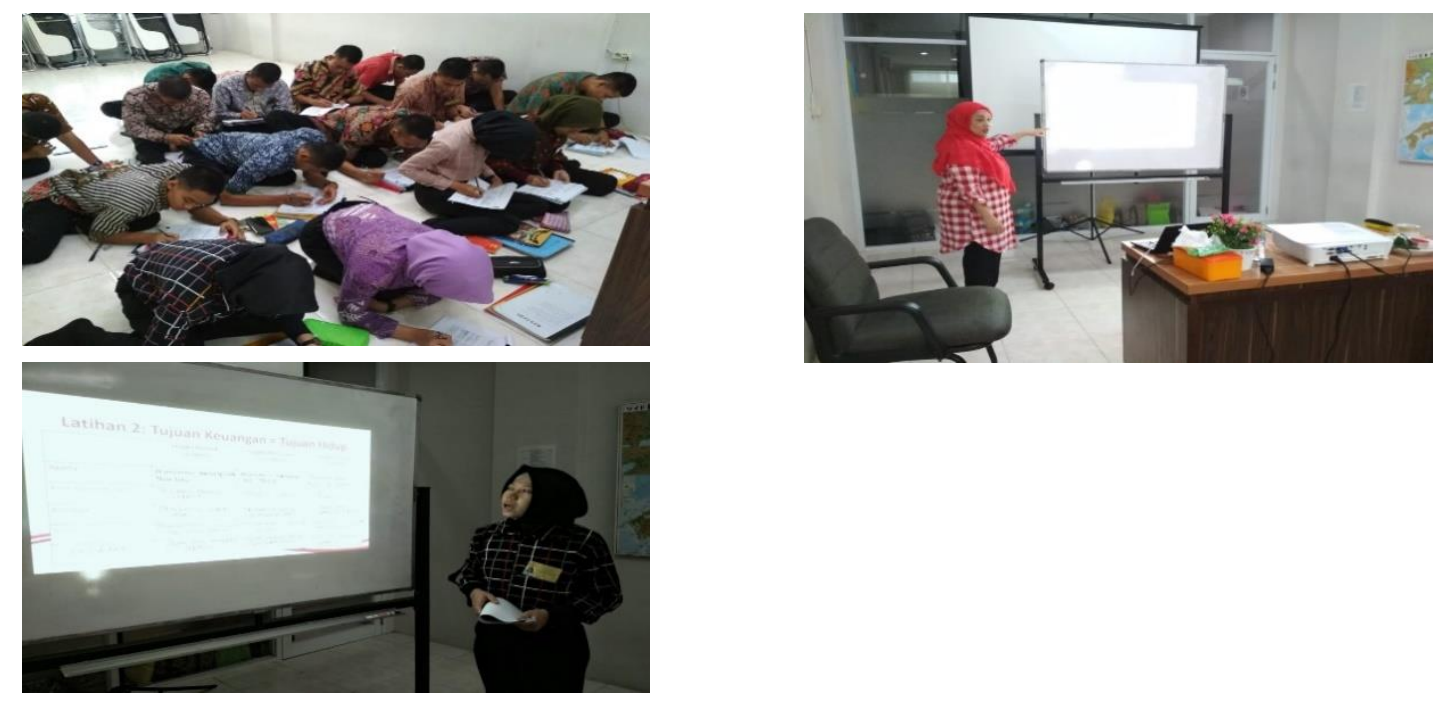

\section{CONCLUSION}

Apprentices after receiving education from these training materials, they gain awareness, knowledge, and skills in financial planning. For prospective interns in Japan regarding finance for future processing, it is vital to know and learn. Understanding financial processing solely for their survival during their internship in Japan or after they return from the course. With the existence of such education, help prospective interns make financial planning in the future before they work with, as they intern in Japan, and after they returned to Indonesia. Helpful so that they no longer have difficulty in meeting the needs of life.

\section{REFERENCE}

Amrizal \& Aji Erland M. (2109), Revision 1 Training Paper Financial Education Candidate Internships in Japan, the Institute of Technology and Business Ahmad Dahlan.

Amrizal \& Aji Erland M, (2109), Revision 3. Financial Plan Candidate Internships in Japan, the Institute of Technology, and Business Ahmad Dahlan.

Febrianty, \& Divianto. (2020). Business Owner'S Perspective on Strategic Execution, Technological Transformation, Competitiveness Potential, and Services Level on the Implementation of Strategic It Alignment. Humanities \& Social Sciences Reviewss, 8(1), 567-585. https://doi.org/10.18510/hssr.2020.8169_1

Rulandari, N., \& Sudrajat, A. (2017). Financial Ratio (Altman Z score) with Statistic Modelling.

Sofyan, M. (2019). Faktor-Faktor Yang Mempengaruhi Profitabilitas Bank Perkreditan Rakyat (BPR) di Provinsi Jawa Timur. Jurnal Inspirasi Bisnis Dan Manajemen, 3(1), 63-76.

The Central Bureau of Statistics, in 2019, rhyming Release May 6, 2019

West Java Governor No. 561/1220-yanbangsos kep/2018 concerning Minimum Wage Regency

/ City in West Java Province in 2019.

JITCO's website: www.jitco.or.jpn

\section{JITCO (2019) 外国人技能実習制度について (About Foreign Technical Training}

System), Ministry of Justice: Immigration Office and Ministry of Health, Labor and Welfare: Human Resources Development Director

Statical Bureau, Ministery of International Affairs and Communication, (2018), Statistical Handbook of Japan, 